\title{
Coronary bifurcation stenting with dedicated Tryton side-branch stent. Early and 6-month results of 40 patients
}

Stentowanie bifurkacji tętnic wieńcowych z zastosowaniem stentu Tryton przeznaczonego do protekcji bocznicy. Obserwacja wczesna i 6-miesięczna 40 pacjentów

\author{
Maciej Lesiak, Katarzyna Stanisławska, Andrzej Drewnicki, Aleksander Araszkiewicz, Włodzimierz Skorupski, \\ Małgorzata Pyda, Marek Grygier, Przemysław Mitkowski, Piotr Bręborowicz, Stefan Grajek \\ $1^{\text {st }}$ Department of Cardiology, Medical University, Poznań, Poland
}

Post Kardiol Interw 2011; 7, 1 (23): 1-7

DOI: $10.5114 /$ pwki.2011.21185

\begin{abstract}
Background: Coronary artery bifurcation stenting using standard stents is associated with increased risk of complications and poor long-term prognosis. Bifurcation-dedicated stents raise a hope of improving the acute and late results of such procedures.

Aim: To assess the early and mid-term results of bifurcation stenting with the specially designed bifurcation-dedicated Tryton side-branch stent.

Methods and results: We evaluated 40 consecutive procedures of coronary artery bifurcation stenting using a Tryton stent in patients with stable angina or acute coronary syndrome without ST elevation. The stent was successfully implanted in 39 patients. The main vessel was treated with drug-eluting stents in 38 cases, whereas bare metal stents were used in the remaining two. In one case the procedure was complicated by non-Q wave myocardial infarction. During 30-day and 6-month observation no additional major adverse cardiac events were observed.

Conclusion: Coronary bifurcation stenting with the Tryton side-branch stent is highly effective, with a low rate of acute and midterm complications.
\end{abstract}

Key words: coronary bifurcation lesion, percutaneous coronary intervention, bifurcation dedicated stents

\section{Streszczenie}

Wstęp: Stentowanie bifurkacji tętnic wieńcowych przy użyciu standardowych stentów obarczone jest zwiększonym ryzykiem powikłań i gorszym rokowaniem odległym. Stenty specjalnie przeznaczone do bifurkacji mogą się przyczynić do poprawy wyników bezpośrednich i odległych zabiegów.

Cel: Ocena wczesnych i średnioterminowych wyników stentowania zwężeń bifurkacji tętnic wieńcowych za pomocą implantacji stentu przeznaczonego do protekcji bocznicy Tryton.

Metody i wyniki: Ocenie poddano kolejnych 40 zabiegów stentowania bifurkacji tętnic wieńcowych z zastosowaniem stentu Tryton u pacjentów z dławicą piersiową stabilną lub ostrym zespołem wieńcowym bez uniesienia odcinka ST. Stent skutecznie implantowano do bocznicy u 39 pacjentów. Naczynie główne leczono implantacją stentu uwalniającego lek w 38 przypadkach, w dwóch implantowano stent metalowy. W jednym przypadku zabieg był powikłany zawałem serca bez wytworzenia załamków Q. W obserwacji 30-dniowej oraz 6-miesięcznej nie stwierdzono żadnych dodatkowych niekorzystnych zdarzeń sercowych.

Wnioski: Leczenie zwężeń bifurkacji tętnic wieńcowych z zastosowaniem stentu Tryton przeznaczonego do protekcji bocznicy cechuje się wysoką skutecznością bezpośrednią i niskim ryzykiem powikłań w obserwacji 30-dniowej i 6-miesięcznej.

Słowa kluczowe: zwężenie bifurkacji tętnic wieńcowych, przezskórne interwencje wieńcowe, stenty przeznaczone do bifurkacji

\section{Introduction}

Percutaneous coronary interventions $(\mathrm{PCl})$ in the area of artery bifurcations are related to higher risk of early complications and to worse long-term outcomes in comparison to procedures involving non-bifurcated segments of the arteries [1]. In the past results of balloon

Corresponding author/Adres do korespondencji:

Maciej Lesiak MD, PhD, 1t Department of Cardiology, Medical University, Długa 1/2, 61-848 Poznań, tel./fax: +48 618549223 ,

e-mail: maciej.lesiak@skpp.edu.pl

Praca wpłynęła 1.11.2010, przyjęta do druku 20.02.2011. 
angioplasty were hard to accept due to the very high rate of restenosis [2]. Introduction of a "kissing" technique (simultaneous inflation of two balloons - one in the main branch and one in the side branch) did not lead to significant improvement [3]. Common use of stents at the end of the 1990s improved the direct results of the procedure, but still did not significantly reduce the restenosis phenomenon. The rate of target lesion revascularization (TLR) remained between 16 and 40\% [4-7]. Significant reduction of in-stent restenosis (ISR) was not obtained until the introduction of drug-eluting stents (DES) which limited the frequency of TLR to several percent $[8,9]$. Soon it became apparent that even those tools are far from optimal, especially in the case of complex lesion stenting (including bifurcation lesions). Classic DES, due to their construction, cannot efficiently protect both arteries when only one stent is implanted. Implantation of two stents is sometimes technically demanding and increases costs of the procedure. Growing access to DES stimulated development of various techniques based on the use of two or more stents. Longterm results of those procedures are still a matter of debate. A major limitation to the use of those stents is the risk of unsuccessful protection against side branch occlusion in the early postprocedural phase and later on against restenosis. Initial studies reported that the frequency of in-segment restenosis may reach $20 \%$ [10, 11]. Stents dedicated to the treatment of coronary artery bifurcations gave hope for safe and effective management of this type of lesion. Their construction allows for successful stenting of the main branch with simultaneous protection of the side branch ostium [12]. The TRYTON stent (Tryton Medical Inc., Newton, MA, USA) is designed for the treatment of coronary artery bifurcations, but its main role is SB protection. The conception is based on the long experience with stenting of the bifurcation lesions with the use of two stents and the "culotte" technique. Implantation of the Tryton stent into the side-branch precedes implantation of any other stent into the main branch. Initial reports on small patient populations confirmed the safety and efficacy of this method. Although this stent does not elute antiproliferating drugs its use together with DES in the main branch leads to minimal late lumen loss in the side-branch which is comparable to the results obtained with the use of the best DES [13, 14]. We present direct results and clinical short- and mid-term follow-up of 40 consecutive patients treated with Tryton stent implantation for bifurcation coronary artery lesions.

\section{Material and methods}

\section{Study group}

Procedures were performed in 40 patients admitted to the $1^{\text {st }}$ Department of Cardiology of the Medical University in Poznan between May 2009 and February 2010. The study included patients with stable coronary artery disease as well as with acute coronary syndromes with exclusion of patients with persistent ST-segment elevation. The decision on the use of Tryton stent was made at the discretion of the interventional cardiologist directly after coronary angiography.

\section{Stent construction and technique of implantation}

The Tryton stent has a cobalt chromium construction and consists of three connected parts: the distal part has the form of a typical "slotted tube" stent and is designed for implantation in the proximal part of the side-branch. The mid part of the stent forms a transition zone with less dense composition and lower radial force. This part covers the bifurcation site after the implantation. It is labelled with two shaft markers to allow accurate stent positioning. The mid part of the stent is connected to the proximal part consisting of three fronds connected at the end with the use of a thin ring. This part of the stent remains in the main branch and its role is to enable the delivery of any stent into the main branch. The stent is assembled in two introduction systems. In the first of them both proximal and distal balloon diameter has $2.5 \mathrm{~mm}$ (a simple type). The second and more frequently used system has a larger diameter of the proximal part of the balloon (3.0-3.5 mm) with distal part of $2.5 \mathrm{~mm}$ (tapered type). Both types of balloon have four markers, two for the beginning and end of the stent and the other two showing the transition zone. The stent construction was described in detail previously [13]. The procedure is most frequently performed with the use of a $6 \mathrm{~F}$ guiding catheter. The Tryton stent is implanted after initial predilatation of the side-branch with the notion that two markers of the transition zone should cover the site of the artery bifurcation. Subsequently, a guidewire is moved from the SB and placed in the MB and used for stent implantation into the main branch. It can be any stent, but implantation of stents eluting antiproliferative drugs is encouraged. None of the procedures described in this study required the use of any additional tools such as a cutting balloon or a rotablator. An example of TRYTON stent implantation is presented in Figure 1.

\section{Pre- and postprocedural management}

All patients received an adequate dose of antiplatelet drugs - aspirin and clopidogrel.

Clopidogrel naive patients received a $600 \mathrm{mg}$ loading dose. After obtaining vascular access all patients received an intravenous injection of unfractionated heparin (100 U/kg of body mass). Glycoprotein Ilb/Illa inhibitors were used provisionally at the discretion of the operator. Patients were discharged from the hospital on life-long aspirin and clopidogrel therapy for 12 months. ECG and concentration of necrosis markers in plasma such as CK-MB and troponin I were assessed routinely on admission to the hospital and on the second day of hospitalization. ECG was also performed directly after the procedure. 

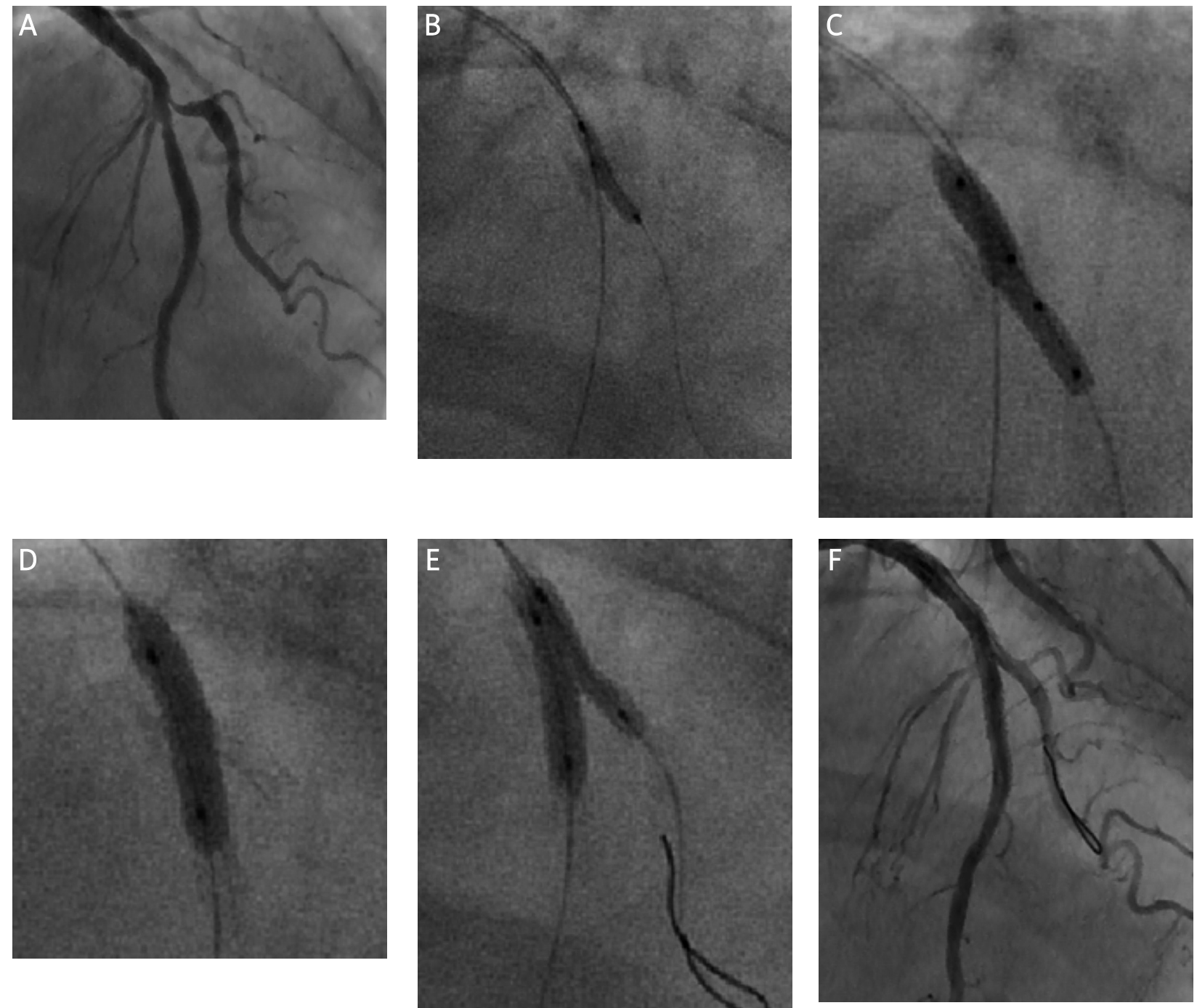

Fig. 1. Tryton stent implantation technique. A - bifurcation lesion, Medina 0,1,1. B - side branch predilatation. C - tryton stent implantation. D - main branch stenting with DES. E - final kissisn balloon postdilatation. $\mathrm{F}$ - the final result

Ryc. 1. Etapy zabiegu z zastosowaniem stentu Tryton. $A$ - zwężenie bifurkacji typu 0,1,1 wg Medina. B - predylatacja bocznicy. $C$ - implantacja stentu Tryton do bocznicy. D - implantacja stentu DES do naczynia gtównego. E-postdylatacja technika kissing. F- bezpośredni wynik zabiegu

\section{Angiographic analysis}

Angiographic changes were analysed by means of the digital analysis system (QCA) included in the Axiom Artis machine software (Siemens). All assessments were performed twice - before and directly after the procedure. An artery reference diameter and its minimal lumen diameter were obtained in three segments: MB before the bifurcation, MB after the bifurcation and SB.

\section{Follow-up}

The analysed procedural and periprocedural complications included death, myocardial infarction, stroke, stent thrombosis and the need for an emergency target vessel revascularization. Follow-up at 30 days and
6 months included death, myocardial infarction, stroke, stent thrombosis and the need for TLR and target vessel revascularization (TVR).

\section{Definitions}

Device success was defined as successful implantation of the Tryton stent with residual stenosis in the SB $<30 \%$ and TIMI 3 flow.

Angiographic success was defined as residual stenosis $<30 \%$ and TIMI flow 3 in the MB and SB. A successful procedure was defined as angiographic success without major adverse cardiovascular events (MACE) during hospitalization. MACE were defined as one of the following: death, $\mathrm{Q}$ wave and non-Q wave myocardial infarction, and 
repeated target lesion revascularization caused by recurrence of ischemia. Myocardial infarction was diagnosed if there was at least 3-fold increase of CK-MB concentration in comparison to the reference values and/or the presence of new, pathological Q waves in at least two contiguous ECG leads. TLR was defined as repeated revascularization of the treated lesion and adjacent segments of the artery up to $5 \mathrm{~mm}$ distance both in $\mathrm{MB}$ and in SB. TVR was defined as repeated revascularization of any of the segments in the treated artery. Stent thrombosis was defined after Academic Research Consortium (ARC) [15].

\section{Results}

The study included the first 40 patients ( 29 men and 11 women) who underwent Tryton stent implantation in the $1^{\text {st }}$ Department of Cardiology of the Medical University of Poznań between July 2009 and February 2010. Mean age of the patients was 65.4 yrs. Detailed demographic and clinical data are presented in Table I.

Of the 40 treated bifurcation lesions 26 (65\%) were considered as true bifurcation lesions with significant stenosis found both in the main branch and in the side branch. Most of the procedures - 28 (70\%) - were conducted on the bifurcation of the left anterior descending artery and diagonal branch and in 3 cases procedures included the left main bifurcation. Reference diameter of the MB before bifurcation was $3.0 \pm 0.3 \mathrm{~mm}$ and after the bifurcation $2.6 \pm 0.3 \mathrm{~mm}$ and SB diameter was $2.4 \pm 0.3 \mathrm{~mm}$. The mean angle between the proximal and the distal segment of the MB and SB was $159 \pm 21^{\circ}$ and

Table 1. Demographic and clinical data of the studied patients

Tabela 1. Dane demograficzne i kliniczne leczonych pacjentów

\begin{tabular}{lc} 
& $N=40, \mathrm{n}(\%)$ \\
\hline Age [years] (mean \pm SD) & $65.4 \pm 8.8$ \\
\hline Male sex & $29(72)$ \\
\hline Diabetes & $18(45)$ \\
\hline Hypertension & $31(78)$ \\
\hline Hypercholesterolaemia & $28(70)$ \\
\hline Positive family history & $16(40)$ \\
\hline Current smoker & $3(8)$ \\
\hline Previous myocardial infarction & $26(65)$ \\
\hline Previous PCl & $24(60)$ \\
\hline Previous CABG & $1(3)$ \\
\hline Stable angina & $33(83)$ \\
\hline Unstable angina/NSTEMI & $7(18)$
\end{tabular}

$P C l$ - percutaneous coronary intervention, $C A B G$ - coronary artery bypass grafting, NSTEMI - non-ST-elevation myocardial infarction
$45 \pm 27^{\circ}$, respectively. Detailed angiographic parameters are summarized in Tables 2 and 3.

Thirty-nine out of 40 stents were successfully implanted. In one case it was impossible to cross the tortuous segment of the artery at the level of the previously implanted stent. In 39 cases a tapered type of stent was used and in one case a straight type of stent was chosen. Drug-eluting stents were implanted into the MB in 38 cases. A bare metal stent was implanted in two cases because of contraindications to prolonged dual antiplatelet therapy. Types of stents implanted into the MB are presented in Table 4. Mean diameter of the stent implanted into the MB was $3.1 \pm 0.3 \mathrm{~mm}$ and its length $24 \pm 6 \mathrm{~mm}$. In 4 patients an additional stent was placed in the SB (DES in 3 cases and BMS in one case). In all cases stents were post-dilated with the use of high pressure "non-compliant" balloons and in 21 patients (51\%) post-dilation was performed with the use of two balloons and the "kissing" technique. Angiographic success was obtained in 39 cases (98\%). Results of the quantitative analysis are presented in Table 3 . In one case the procedure was complicated by non-Q wave myocardial infarction due to spiral dissection of the tortuous main branch caused by a guidewire placed in the artery segments located distally to the initial stenosis. Detailed procedural data are presented in Table 5.

Table 2. Description of treated lesions Tabela 2. Opis leczonych zwężeń

\begin{tabular}{|c|c|}
\hline Change & $N=40, n(\%)$ \\
\hline \multicolumn{2}{|l|}{ Lesion location } \\
\hline Left main & $3(8)$ \\
\hline $\mathrm{LAD} / \mathrm{DIA}$ & $28(70)$ \\
\hline $\mathrm{LCX} / \mathrm{OM}$ & $5(13)$ \\
\hline RCA & $3(8)$ \\
\hline other & $1(3)$ \\
\hline \multicolumn{2}{|l|}{ Medina classification } \\
\hline $1,1,1$ & $18(45)$ \\
\hline $1,1,0$ & $6(15)$ \\
\hline $1,0,1$ & $4(10)$ \\
\hline $1,0,0$ & $5(13)$ \\
\hline $0,1,1$ & $2(5)$ \\
\hline $0,1,0$ & $3(8)$ \\
\hline $0,0,1$ & $2(5)$ \\
\hline \multicolumn{2}{|l|}{ ACC classification } \\
\hline $\mathrm{A}$ & 0 \\
\hline B1 & $5(13)$ \\
\hline $\mathrm{B} 2$ & $21(53)$ \\
\hline $\mathrm{C}$ & $14(35)$ \\
\hline Multivessel coronary artery disease & $23(58)$ \\
\hline
\end{tabular}


Table 3. Quantitative angiographic analysis

Tabla 3. Angiograficzna analiza ilościowa

\begin{tabular}{|c|c|c|}
\hline & $\begin{array}{c}\text { Before } \\
\text { the procedure }\end{array}$ & $\begin{array}{c}\text { After } \\
\text { the procedure }\end{array}$ \\
\hline \multicolumn{3}{|l|}{ MB prox. } \\
\hline $\mathrm{MLD}[\mathrm{mm}]$ & $1.06 \pm 0.53$ & $2.98 \pm 0.22$ \\
\hline $\mathrm{RD}[\mathrm{mm}]$ & $3.02 \pm 0.31$ & $3.17 \pm 0.24$ \\
\hline Stenosis [\%] & $64 \pm 19$ & $6 \pm 3$ \\
\hline Lumen increase [mm] & - & $1.92 \pm 0.604$ \\
\hline \multicolumn{3}{|l|}{ MB dist. } \\
\hline $\mathrm{MLD}[\mathrm{mm}]$ & $1.12 \pm 0.79$ & $2.66 \pm 0.27$ \\
\hline $\mathrm{RD}[\mathrm{mm}]$ & $2.61 \pm 0.30$ & $2.78 \pm 0.22$ \\
\hline Stenosis [\%] & $58 \pm 29$ & $4 \pm 6$ \\
\hline Lumen increase [mm] & - & $1.54 \pm 0.73$ \\
\hline \multicolumn{3}{|l|}{ SB } \\
\hline $\mathrm{MLD}[\mathrm{mm}]$ & $1.20 \pm 0.66$ & $2.22 \pm 0.29$ \\
\hline $\mathrm{RD}[\mathrm{mm}]$ & $2.40 \pm 0.26$ & $2.49 \pm 0.17$ \\
\hline Stenosis [\%] & $49 \pm 29$ & $11 \pm 10$ \\
\hline Lumen increase [mm] & - & $1.02 \pm 0.65$ \\
\hline \multicolumn{3}{|c|}{ Bifurcation angles [degrees] } \\
\hline MB prox. / SB & $159 \pm 21$ & \\
\hline MB dist. / SB & $45 \pm 27$ & \\
\hline
\end{tabular}

$M L D$ - minimal lumen diameter, $R D$ - reference diameter, $M B$ prox. main branch proximal to bifurcation, MB dist. - main branch distal to bifurcation, $S B$ - side-branch

\section{In-hospital, 30-day and 6-month follow-up}

Thirty-nine patients were discharged home without complications. One patient had a significant increase of the troponin I and CK-MB concentrations characteristic for non-Q wave myocardial infarction (after a complicated procedure). Thirty-day and 6-month follow-up was performed in all patients. There were no deaths, myocardial infarctions, strokes, stent thrombosis or repeated revascularizations. All patients remained on dual antiplatelet therapy. Repeated coronary angiography was performed in 15 patients within 6 months after the procedure. The indication for angiography was the need for $\mathrm{PCl}$ on another coronary artery or a suspicion of instent restenosis. There were no cases of restenosis either in the main branch or in the side branch.

\section{Discussion}

Stenting of coronary artery bifurcations with the use of BMS or DES is related to higher risk of early complications and a worse long-term prognosis in comparison to non-bifurcated artery segments stenting [1, 10, 16]. Reduction of restenosis rate by introduction of DES led to the development of many techniques based on the implantation of two or more stents [17]. However, none of them was superior to MB stenting with the use of a single stent and provisional side-branch stenting [18-21]. Besides,
Table 4. Types of stents implanted into the MB Tabela 4. Stenty implantowane do naczynia gtównego

\begin{tabular}{lcc} 
Name & Drug & Number of cases \\
\hline Xience Prime & Everolimus & 15 \\
\hline Endeavor Resolute & Zotarolimus & 5 \\
\hline Xience V & Everolimus & 4 \\
\hline Taxus Liberté & Paclitaxel & 4 \\
\hline Promus & Everolimus & 3 \\
\hline Taxcor & Paclitaxel & 3 \\
\hline Cypher Select & Sirolimus & 1 \\
\hline Biomatrix & Biolimus A9 & 1 \\
\hline Coroflex Please & Paclitaxel & 1 \\
\hline Luc - Chopin & Paclitaxel & 1 \\
\hline Skylor & None & 1 \\
\hline Liberte & None & 1
\end{tabular}

Table 5. Description and results of the procedure Tabela 5. Opis i wyniki zabiegu

\begin{tabular}{|c|c|}
\hline \multicolumn{2}{|l|}{ Predilatation } \\
\hline $\mathrm{SB}$ & $34(85 \%)$ \\
\hline$M B$ & $36(90 \%)$ \\
\hline Postdilatation & $40(100 \%)$ \\
\hline Kissing & $21(52 \%)$ \\
\hline \multicolumn{2}{|l|}{ Additional stent implantation* } \\
\hline $\mathrm{SB}$ & $4(10 \%)$ \\
\hline$\overline{M B}$ & $5(12 \%)$ \\
\hline Total number of implanted stents & 89 \\
\hline Number of stents / patient & 2.2 \\
\hline Result of the procedure & $N=40$ \\
\hline Successful implantation of the Tryton stent & 39 \\
\hline Angiographic success & 39 \\
\hline Periprocedural myocardial infarction & 1 \\
\hline Successful procedure & 39 \\
\hline 30-day and 6-month follow-up & $N=40$ \\
\hline Death & $0 / 0$ \\
\hline Myocardial infarction & $1 / 1$ \\
\hline TLR & $0 / 0$ \\
\hline TVR & $0 / 0$ \\
\hline Stent thrombosis (definite/probable/possible) & $0 / 0$ \\
\hline MACE & $1 / 1$ \\
\hline $\begin{array}{l}\text { *other than Tryton stent and an MB stent } \\
T L R \text {-repeat target lesion revascularization, TVR -r } \\
\text { revascularization, MACE - major adverse cardiovasC } \\
\text { myocardial infarction, repeat revascularization) }\end{array}$ & $\begin{array}{l}\text { et lesion } \\
\text { s (death, }\end{array}$ \\
\hline
\end{tabular}

despite significant progress in the stenting of bifurcation lesions multi-stent techniques are related to higher risk of periprocedural complications, mainly non-Q wave myo- 
cardial infarctions, not to mention the costs [19-21]. The reason is that conventional stents were not designed for stenting of lesions including artery bifurcations. Stent implantation into the main branch at the level of the sidebranch ostium leads to dislocation of the carina in that direction and side-branch lumen narrowing even if initially there were no significant changes in the side branch [22]. This phenomenon unnecessarily pushes the operator towards additional stent implantation into the side branch. Implantation of two stents in an anatomically complex location such as bifurcation often leads to further problems. Stent introduction through the struts of another stent may be difficult itself. Desirable expansion of the area of stent overlap is very often impossible and requires high pressures which in turn increase procedural trauma. This type of procedure is also related to longer patient stay in the cath $l a b$, and increases the volume of administered contrast agents and the dose of $X$-ray radiation. The method of coronary artery bifurcation stenting presented in this study is based on longstanding experience with the use of a "culotte" technique, but in this case one of the stents has a special structure designed to suit the anatomy of artery bifurcation. The "culotte" technique did not work out in the BMS era, because of the very high frequency of restenosis [23]. However, the use of DES seems to make this technique safe and very efficacious [24-27]. The NORDIC study demonstrated that the "culotte" technique is safer than the "crush" technique (lower rate of periprocedural infarctions) and is related to lower risk of restenosis in the long term ( $4.5 \%$ vs. $10.5 \%$ ) [27]. The Tryton stent was designed based on the "culotte" technique, and in this case the procedure begins with side-branch stenting. As demonstrated by our results this method is effective and safe for the patients. There were no cases of main branch occlusion caused by preceding implantation of the Tryton stent into the side-branch. Similar to the FIM study [14] our direct and long-term results are very good. There is a very high success rate of stent implantation (98\%) which is comparable or superior to the success rate of techniques using 2 stents [24]. There were no cases of repeat revascularization caused by restenosis in the treated segment at 6-month follow-up. So far there have been only a few studies published on the role of stents dedicated for coronary artery bifurcation stenting. Analysis of 50 patients treated with the use of the Frontier ${ }^{\mathrm{TM}}$ stent was able to demonstrate a $92 \%$ success rate and the need for a repeat revascularization was up to $10 \%$ [28]. In the first human study on the implantation of the Taxus Petal stent dedicated for bifurcation lesions Ormiston et al. observed a low implantation success rate (89\%) [29]. The frequency of TLR was $7.4 \%$ at 1 year. The self-expanding Axxess stent eluting an antiproliferating drug - biolimus was assessed in the DIVERGE trial. The stent was implanted above the bifurcation which was related to its particular construction. In most of the 300 treated patients (64.7\%) the procedure required implantation of two additional stents. There was a low 9-month MACE rate $(7.7 \%)$ and a restenosis rate of $6 \%$ while TLR was observed in $4.3 \%$ [30]. In comparison to the above studies the Tryton stent seems to be a more effective and safe tool with a low risk of adverse events both at short- and at long-term follow-up. This is confirmed by the results of the e-Tryton registry presented at the last TCT conference [31]. Follow-up of 302 patients showed a $99 \%$ success rate with no deaths and a few cases of periprocedural infarction (1.4\%). At 6-month follow-up there were no deaths, myocardial infarction was diagnosed in two patients and a repeat TLR was performed in $3.6 \%$ of patients $(2.4 \%$ in $\mathrm{MB}$ and $1.2 \%$ in $\mathrm{SB})$.

\section{Conclusion}

The Tryton stent, dedicated for side branch protection, is a safe and effective tool for the treatment of bifurcation lesions in the coronary arteries. Randomized studies on large patient populations are required to definitively assess its role in percutaneous coronary interventions.

\section{References}

1. Al Suwaidi J, Yeh W, Cohen HA, et al. Immediate and one-year outcome in patients with coronary bifurcation lesions in the modern era (NHLBI dynamic registry). Am J Cardiol 2001; 87: 1139-1144.

2. Zack PM, Ischinger T. Experience with a technique for coronary angioplasty of bifurcational lesions. Cathet Cardiovasc Diagn 1984; 10: 4334-4343.

3. George BS, Myler RK, Stertzer SH, et al. Balloon angioplasty of bifurcation lesions: the kissing balloon technique. Cathet Cardiovasc Diagn 1986; 12: 124-138.

4. Castriz JL, Canales ML, Reynolds DW. Kissing balloon technique in complex PTCA. Cathet Cardiovasc Diagn 1993; 28: 358-369.

5. Pan M, Suarez de Lezo J, Medina A, et al. Simple and complex stent strategies for bifurcated coronary artery stenosis involving the side branch origin. Am J Cardiol 1999; 83: 1320-1325.

6. Al Suwaidi J, Berger PB, Rihal CS, et al. Immediate and long-term outcome of inracoronary stent implantation for true bifurcation lesions. J Am Coll Cardiol 2000; 35: 929-936.

7. Lefevre T, Louvard Y, Morice MC, et al. Stenting of bifurcation lesions: classification, treatment and results. Catheter Cardiovasc Interv 2000; 49: 274-283.

8. Moses J, Leon M, Popma J, et al. (for the SIRIUS Investigators). Sirolimus-Eluting Stents versus Standard Stents in Patients with Stenosis in a Native Coronary Artery. N Engl J Med 2003; 349: 1315-1323.

9. Stone GW, Ellis SG, Cox DA, et al. One-Year Clinical Results With the Slow-Release, Polymer-Based, Paclitaxel-Eluting TAXUS Stent The TAXUS-IV Trial. Circulation 2004; 109: 1942-1947.

10. Colombo A, Moses JW, Morice MC, et al. Randomized study to evaluate sirolimus-eluting stents implanted at coronary bifurcation lesions. Circulation 2004; 109: 1244-1249.

11. Tanabe K, Hoye A, Lemos PA, et al. Restenosis rates following bifurcation stenting with sirolimus-eluting stents for de novo narrowings. Am J Cardiol 2004; 94: 115-118.

12. Latib A, Colombo A, Sangiorgi GM. Bifurcation stenting: current strategies and new devices. Heart 2009; 95: 495-504.

13. Kaplan AV, Davis HR. Tryton side-branch stent. Eurolntervention 2006; 2: 270-271. 
14. Onuma Y, Muller R, Ramcharitar S, et al. Tryton I First-In-Man (FIM) study: six month clinical and angiographic outcome, analysis with a new quantitative coronary angiography dedicated for bifurcation lesions. Eurolntervention 2008; 3: 546-552.

15. Cutlip DE, Windecker S, Mehran R, et al. Academic Research Consortium. Clinical end points in coronary stent trials: a case for standardized definitions. Circulation 2007; 115: 2344-2351.

16. Lemos PA, Hoye A, Goedhart D, et al. Clinical, angiographic, and procedural predictors of angiographic restenosis after sirolimuseluting stent implantation in complex patients: an evaluation from the Rapamycin-Eluting Stent Evaluated At Rotterdam Cardiology Hospital (RESEARCH) study. Circulation 2004; 109: 1366-1370.

17. Louvard Y, Thomas M, Dzavik V, et al. Classification of coronary artery bifurcation lesions and treatments: time for a consensus! Catheter Cardiovasc Interv 2008; 71: 175-183.

18. Colombo A, Bramucci E, Saccà S, et al. Randomized study of the crush technique versus provisional side-branch stenting in true coronary bifurcations: The CACTUS (Coronary Bifurcations: Application of the Crushing Technique Using Sirolimus-Eluting Stents) study. Circulation 2009; 119: 71-78.

19. SteigenTK, Maeng M, Wiseth R, et al. Nordic PCI Study Group. Randomized study on simple versus complex stenting of coronary artery bifurcation lesions: the Nordic bifurcation study. Circulation. 2006; 114: 1955-1961.

20. Jensen JS, Galløe A, Lassen JF, et al. Nordic-Baltic PCI Study Group. Safety in simple versus complex stenting of coronary artery bifurcation lesions. The Nordic bifurcation study 14-month followup results. Eurolntervention 2008; 4: 229-233.

21. Hildick-Smith D, de Belder AJ, Cooter N, et al. Randomized Trial of Simple Versus Complex Drug-Eluting Stenting for Bifurcation Lesions. The British Bifurcation Coronary Study: Old, New, and Evolving Strategies. Circulation 2010; 121: 1235-1243.

22. Vassilev D, Gil R. Relative dependence of diameters of branches in coronary bifurcations after stent implantation in main vessel importance of carina position. Kardiol Pol 2008; 66: 371-378.
23. Al Suwaidi J, Berger PB, Rihal CS, et al. Immediate and long-term outcome of intracoronary stent implantation for true bifurcation lesions. J Am Coll Cardiol 2000; 35: 929-936.

24. Kaplan S, Barlis P, Dimopoulos K, et al. Culotte versus T-stenting in bifurcation lesions: immediate clinical and angiographic results and midterm clinical follow-up. Am Heart J 2007; 154: 336-343.

25. Hoye A, van Mieghem CA, Ong AT, et al. Percutaneous therapy of bifurcation lesions with drug-eluting stent implantation: the Culotte technique revisited. Int J Cardiovasc Intervent 2005; 7: 36-40.

26. Adriaenssens T, Byrne RA, Dibra A, et al. Culotte stenting technique in coronarybifurcation disease: angiographic follow-up using dedicated quantitative coroanry angiographic analysis and 12month clinical outcomes. Eur Heart J 2008; 29: 2868-2876.

27. Erglis A, Kumsars I, Niemelä M, et al. Nordic PCI Study Group. Randomized comparison of coronary bifurcation stenting with the crush versus the culotte technique using sirolimus eluting stents: the Nordic stent technique study. Circ Cardiovasc Interv 2009; 2: 27-34.

28. Lesiak M, Rzeźniczak J, Hiczkiewicz J i wsp. Angioplastyka bifurkacji wieńcowych z zastosowaniem stentu Multilink Frontier. Obserwacja odległa 50 pacjentów. Post Kardiol Interw 2005; 1: 35-43.

29. Ormiston JA, Lefèvre T, Grube $E$, et al. First human use of the TAXUS Petal paclitaxel-eluting bifurcation stent. Eurolntervention 2010; 6: 46-53.

30. Verheye S, Agostoni P, Dubois CL, et al. 9-month clinical, angiographic, and intravascular ultrasound results of a prospective evaluation of the Axxess self-expanding biolimus A9-eluting stent in coronary bifurcation lesions: the DIVERGE (Drug-Eluting Stent Intervention for Treating Side Branches Effectively) study. J Am Coll Cardiol 2009; 53: 1031-1039.

31. Foley D. E-TRYTON 150 and Benelux. A "real-world" all comers multicenter registry. Prezentacja na TCT, Waszyngton 2010. 